\title{
Regulation of pancreatic islet gene expression in mouse islets by pregnancy
}

\author{
B T Layden, V Durai, M V Newman, A M Marinelarena, C W Ahn, G Feng ${ }^{1}$, S Lin ${ }^{1}$, X Zhang ${ }^{2}$, \\ D B Kaufman², N Jafari ${ }^{3}$, G L Sørensen ${ }^{4}$ and W L Lowe Jr
}

Division of Endocrinology, Metabolism and Molecular Medicine, Department of Medicine, Northwestern University Feinberg School of Medicine, 303 East Chicago Avenue, Tarry 15, Chicago, Illinois 60611, USA

${ }^{1}$ Northwestern University Biomedical Informatics Center, ${ }^{2}$ Division of Transplantation Surgery, Department of Surgery and ${ }^{3}$ Genomics Core, Center for Genetic Medicine, Northwestern University, Chicago, Illinois 60611, USA

${ }^{4}$ Medical Biotechnology Center, University of Southern Denmark, DK-5000 Odense C, Denmark

(Correspondence should be addressed to W L Lowe Jr; Email: wlowe@northwestern.edu)

\begin{abstract}
Pancreatic $\beta$ cells adapt to pregnancy-induced insulin resistance by unclear mechanisms. This study sought to identify genes involved in $\beta$ cell adaptation during pregnancy. To examine changes in global RNA expression during pregnancy, murine islets were isolated at a time point of increased $\beta$ cell proliferation (E13.5), and RNA levels were determined by two different assays (global gene expression array and G-protein-coupled receptor (GPCR) array). Follow-up studies confirmed the findings for select genes. Differential expression of 110 genes was identified and follow-up studies confirmed the changes in select genes at both the RNA and protein level. Surfactant protein D (SP-D) mRNA and protein levels exhibited large increases, which
\end{abstract}

were confirmed in murine islets. Cytokine-induced expression of SP-D in islets was also demonstrated, suggesting a possible role as an anti-inflammatory molecule. Complementing these studies, an expression array was performed to define pregnancy-induced changes in expression of GPCRs that are known to impact islet cell function and proliferation. This assay, the results of which were confirmed using realtime reverse transcription-PCR assays, demonstrated that free fatty acid receptor 2 and cholecystokinin receptor A mRNA levels were increased at E13.5. This study has identified multiple novel targets that may be important for the adaptation of islets to pregnancy.

Journal of Endocrinology (2010) 207, 265-279

\section{Introduction}

Pancreatic $\beta$ cells within the islets of Langerhans play a critical role in the regulation of glucose homeostasis by sensing glucose levels and secreting insulin. Compensation in response to increased demands for insulin occurs through changes in both insulin synthesis and release, as well as changes in $\beta$ cell mass. These changes observed in $\beta$ cells play an important role in regulating glucose homeostasis during different physiological and pathological states such as the insulin resistant states of pregnancy and obesity (Butler et al. 2007). Studying states in which insulin needs change can provide insight into pathways mediating $\beta$ cell adaptations.

In mice, $\beta$ cell mass increases about twofold during pregnancy, with a maximum rate of $\beta$ cell proliferation near day 14 post coitum. This response is dynamic, as $\beta$ cell mass decreases in the postpartum period (Karnik et al. 2007). Although the activation of the prolactin receptor (PRLR) by prolactin and placental lactogens contributes to the regulation of $\beta$ cell mass during pregnancy (Brelje et al. 1993), the mechanisms controlling the expansion of $\beta$ cell mass during pregnancy remain incompletely defined, and it is likely that additional signaling pathways contribute to or are directly involved in the PRLR-mediated proliferative response (Karnik et al. 2007, Sorenson \& Brelje 2009).

This study was designed to begin to elucidate the molecular mechanisms responsible for pregnancy-induced changes in $\beta$ cell mass. This was accomplished by comparing the results of whole genome RNA expression analysis using islets from pregnant mice on day E13.5 and control mice. We identified 110 genes that are differentially expressed in pregnant islets, including the gene encoding surfactant protein D (SP-D). Furthermore, the impact of pregnancy on the expression of G-protein-coupled receptors (GPCRs), a family of proteins involved in the regulation of $\beta$ cell function and mass and effectors for a number of therapeutic agents (Vasavada et al. 1996, Holz \& Chepurny 2005, Xiao et al. 2008), was examined in detail using a separate but complementary microarray approach. Together, the results of our studies suggest multiple novel targets that will facilitate further studies seeking to define molecular changes characteristic of the pregnancy-induced increase in $\beta$ cell mass. 


\section{Materials and Methods}

\section{Islet isolation}

C57BL/ 6 pregnant (day 13.5 of pregnancy) and control (ageand sex-matched) mice were purchased from Jackson Laboratories (Bar Harbor, ME, USA). Islets were isolated using standard protocols as described previously (Chen et al. 2006), and RNA was isolated using RNeasy (Qiagen). For RNA analyses, islets isolated from three mice were pooled for each sample to reduce interindividual variability in the RNA expression analyses. All procedures performed on animals were approved by the Northwestern University Animal Care and Use Committee.

\section{Microarray analysis}

RNA expression analysis was performed using the Illumina MouseWG-6 BeadChip, which provides coverage of over 45200 genes and expressed sequence tags. Islet RNA from pregnant and control mice was labeled using a commercial kit (TargetAmp 1-Round Aminoallyl-aRNA Ki; Epicentre, Madison, WI, USA). To reduce changes related to interindividual variability, each sample of islet RNA was prepared using pooled islets from three pregnant or control mice. Labeled RNA was hybridized to microarrays. Raw signal intensities of each probe were obtained and processed as described previously (Du et al. 2008). Differentially expressed genes were identified using an ANOVA model with empirical Bayesian variance estimation. The problem of multiple comparisons was corrected using the false discovery rate (FDR). Genes were identified as being differentially expressed on the basis of a statistical significance $(P$ value $<0 \cdot 01)$, FDR $<5 \%$, and 1.5 -fold change in expression level in pregnant compared with control islets. Functional classification was performed using the ingenuity pathway analysis (IPA) software, based on statistical significance (IPA pathway test, $P<0 \cdot 01)$ and biological importance.

\section{GPCR RNA array}

A commercially available GPCR-specific 384 well TaqMan real-time reverse transcription (RT)-PCR microarray (Applied Biosystems, Carlsbad, CA, USA), which allows for the detection of mRNAs encoding 343 GPCRs (not including the odorant, olfactory, gustatory, and pheromone receptors), was used with RNA extracted as described above. cDNA was prepared using the high-capacity reverse transcriptase kit (Applied Biosystems) from the RNA that had contaminating DNA removed by DNAase I (Ambion, Applied Biosystems, Austin, TX, USA), and each port was loaded with cDNA (from $1 \mu \mathrm{g}$ RNA) and the TaqMan Gene Expression Master Mix (Applied Biosystems). The resulting plate was analyzed on the 7900HT ABI PRISM, and the data were analyzed using SDS 2.3 and RQ Manager 1.2 software provided by Applied Biosystems. The results for each individual GPCR were examined, and if the sample had a calculated threshold $<0 \cdot 1$, it was defined as undetectable (this generally indicated no discernible melt curve) and for data processing, the cycle time $\left(C_{\mathrm{t}}\right)$ was set at $40 \cdot 0$. A comparative $C_{\mathrm{t}}$ approach was utilized to quantify the relative levels of mRNA. $C_{\mathrm{t}} \mathrm{s}$ were normalized to the geometric mean of three housekeeping (HK) genes. Each HK gene on the microarray was evaluated for stability by geNorm (Vandesompele et al. 2002), and the three most stable HK genes were used. This experiment was performed on two independent samples, where each sample consisted of islets pooled from three mice.

\section{Real-time RT-PCR}

RNA was isolated and cDNA was prepared as described above. cDNA samples were examined by real-time RT-PCR and were normalized to the geometric mean of the three most stable HK genes as determined by geNorm (Vandesompele et al. 2002). These were hypoxanthine-guanine phosphoribosyltransferase (HPRT), TATA-binding protein (TBP), and peptidylprolyl isomerase A (PPIA). Sequences of primers used in the different assays are listed in Supplementary Table 1, see section on supplementary data given at the end of this article. A comparative $C_{\mathrm{t}}$ analysis was utilized to determine fold change in RNA expression based on the following approach: fold change $=2^{\left(\Delta \Delta C_{t}\right)}=2^{-\left(\Delta C_{t} \text { sample }-\Delta C_{t} \text { control) }\right.}$ (Fleige et al. 2006). For each real-time RT-PCR experiment, three independent replicates were used.

\section{Western blot}

Islets from the control or pregnant mice (day 13.5 of pregnancy) were isolated as described above, and proteins were extracted in RIPA cell lysis buffer containing a cocktail of protease inhibitors (Calbiochem, LaJolla, CA, USA). Primary antibodies for free fatty acid receptor 2 (FFAR2) and PRLR were from Santa Cruz (Santa Cruz, CA, USA) and for tryptophan hydroxylase 1 (TPH1) from Thermo Scientific (Rockford, IL, USA). Mouse monoclonal antibodies to SP-D (hyb-246) were prepared as described earlier (Sorensen et al. 2009). The protein content of the lysate was determined using the Coomassie blue protein assay. Twenty micrograms of protein were separated by $10 \%$ SDS-PAGE and transferred to a polyvinylidene fluoride membrane in a semidry apparatus. Western blot analyses were performed as previously described (El Muayed et al. 2010). For SP-D samples, both reduced and nonreduced protein samples were examined. For reduced samples for SP-D, protein preparations were prepared by mixing the protein samples 1:2 with Laemmli sample buffer with $5 \% 2$-mercaptoethanol and heating at $100{ }^{\circ} \mathrm{C}$ for $1 \mathrm{~min}$ (nonreduced preparations were heated in sample buffer with the addition of iodoacetamide, final concentration of $90 \mathrm{mM}$ ) as previously described (Madsen et al. 2000, Sørensen et al. 2009). Each assay was repeated with two or three independent samples. 


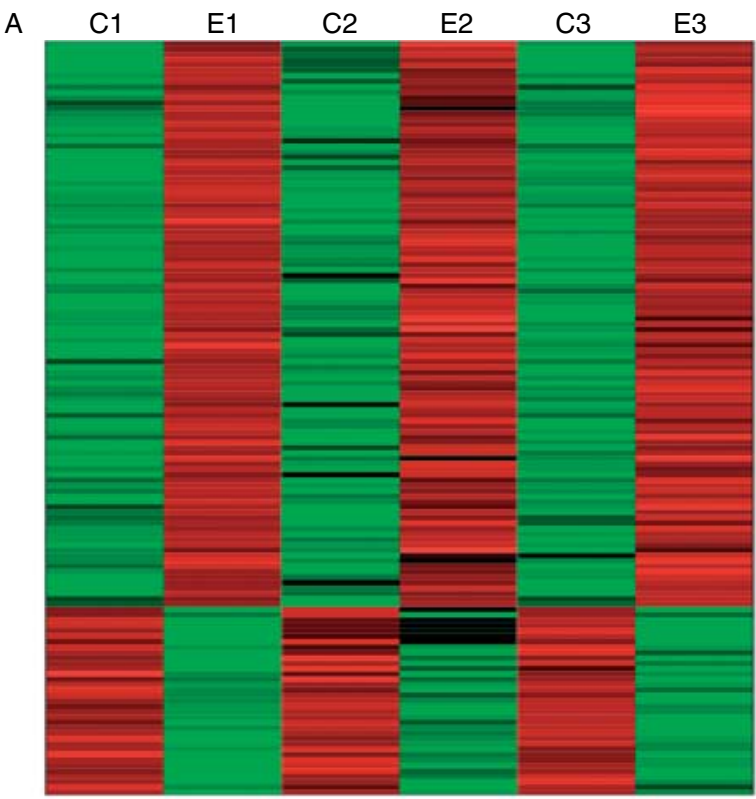

Scale bar fold change in RNA expression

Decreased Increased

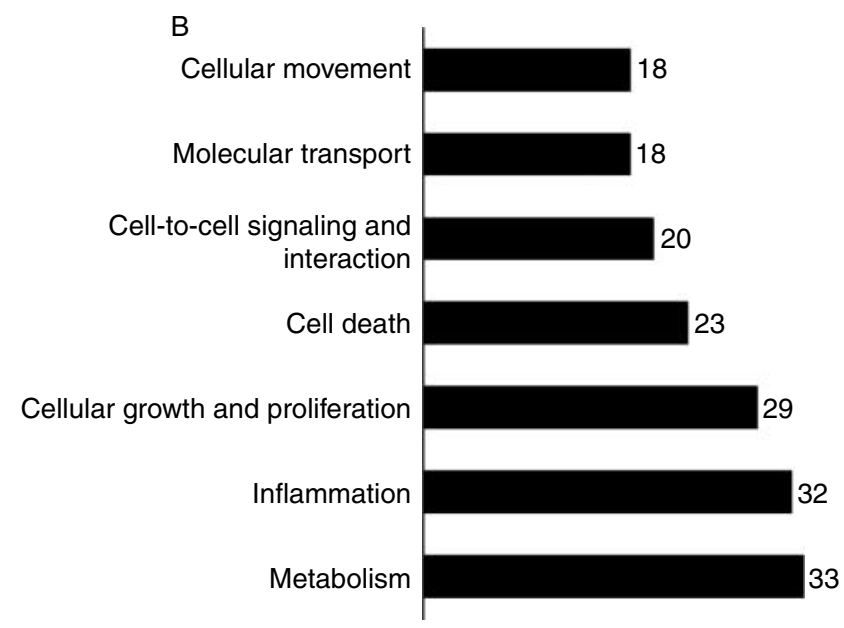

Figure 1 Global gene expression analysis of pancreatic islets at day 13.5 of pregnancy. (A) Heat map of differentially regulated pancreatic islet genes in pooled islets from either pregnant mice on day 13.5 (E1-E3) or control mice. E1, E2, C1, and C2 represent independent samples prepared from separate pools of pregnant (E1 and 2) and control (C1 and 2) islets. E3 and C3 are data obtained using the same RNA as E1/C1 respectively but prepared for microarray analysis independently. Scale bar: relative RNA expression (mean centered, standardized).

(B) Graphical representation of the 110 differentially regulated genes from islets of pregnant mice compared with those of control mice using a functional classification scheme from ingenuity. Genes could be included in more than one category. The number of genes in each category is shown. $P$ values for each category were determined by a category overrepresentation $P$ test to examine the relative proportion of the genes in each category among the differentially regulated genes compared with the chip as a whole. The $P$ values were as follows: cellular movement $\left(P=2 \cdot 9 \times 10^{-3}\right)$, molecular transport $\left(P=4 \cdot 5 \times 10^{-4}\right)$, cell-to-cell signaling and interaction $\left(P=4 \cdot 5 \times 10^{-4}\right)$, cell death $\left(P=9 \cdot 3 \times 10^{-4}\right)$, cellular growth and proliferation $\left(P=4 \cdot 5 \times 10^{-4}\right)$, inflammation $\left(P=1 \cdot 5 \times 10^{-2}\right)$, and metabolism $\left(P=3 \cdot 4 \times 10^{-3}\right)$. 
Table 1 Global expression analysis of RNA isolated from pregnant mice (E13·5) compared with that from control mice (age- and sex-matched)

Genes

Cell-to-cell signaling and interaction

Sftpd

Tph1

Tnfrsf11b

Vip

Tac1

Prlr

C3

Cartpt

Glycam 1

Grp

Clqa

Ttyh1

Ffar2

Ptpre

Ntrk2

Lpl

Pcsk9

Rap2a

Ibsp

Spon2

Cellular growth and proliferation

Sftpd

Cish

Tnfrsf1 1b

Vip

Nupr1

Ovol2

Tac1

Socs 2

Igfbp-5

Hopx

Enpp2

Prlr

C3

Grp

Gadd $45 \alpha$

Apobec1

Dnmt3b

Mcfd2

Eif4ebp-1

Cited2

Ptpre

Fgl2

Fhit

Isg20

Ntrk2

Defb1

Tox

Fosb

Tm4sf4

Molecular transport

Sttpd

Tnfrsf $11 b$

Vip

Tac1

Igfbp-5

Enpp2

Prlr

C3

Grp
Description

Surfactant-associated protein D

Tryptophan hydroxylase 1

Osteoprotegerin

Vasoactive intestinal polypeptide

Tachykinin 1

Prolactin receptor

Complement component 3

CART prepropeptide

Glycosylation-dependent cell adhesion molecule 1

Gastrin-releasing peptide

Complement component 1, q subcomponent, alpha polypeptide

Tweety homolog 1 (Drosophila)

Free fatty acid receptor 2

Protein tyrosine phosphatase, receptor type, E

Neurotrophic tyrosine kinase, receptor, type 2

Lipoprotein lipase

Proprotein convertase subtilisin/kexin type 9

RAS-related protein $2 \mathrm{a}$

Integrin-binding sialoprotein

Spondin 2, extracellular matrix protein

Surfactant-associated protein D

Cytokine-inducible $\mathrm{SH} 2$-containing protein

Osteoprotegerin

Vasoactive intestinal polypeptide

Nuclear protein 1

Ovo-like 2 (Drosophila)

Tachykinin 1

Suppressor of cytokine signaling 2

Insulin-like growth factor-binding protein-5

HOP homeobox

Ectonucleotide pyrophosphatase/phosphodiesterase 2

Prolactin receptor

Complement component 3

Gastrin-releasing peptide

Growth arrest and DNA-damage-inducible 45 alpha

Apolipoprotein B editing complex 1

DNA methyltransferase 3B

Multiple coagulation factor deficiency 2

Eukaryotic translation initiation factor $4 \mathrm{E}-$ binding protein-1

$\mathrm{Cbp} / \mathrm{p} 300$-interacting transactivator, w/Glu/Asp carb.-terminaldom.2

Protein tyrosine phosphatase, receptor type, $\mathrm{E}$

Fibrinogen-like protein 2

Fragile histidine triad gene

Interferon-stimulated protein

Neurotrophic tyrosine kinase, receptor, type 2

Defensin beta 1

Thymocyte selection-associated high-mobility group box

FBJ osteosarcoma oncogene B

Transmembrane 4 superfamily member 4

Fold

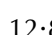

$3 \cdot 7$

$2 \cdot 9$

$2 \cdot 6$

$-1 \cdot 5$

$-1 \cdot 5$

$-1 \cdot 6$

$-1 \cdot 7$

$-1 \cdot 7$

$12 \cdot 8$

$-1 \cdot 5$

$-1 \cdot 5$

$-1 \cdot 7$

Surfactant-associated protein D

Osteoprotegerin

Vasoactive intestinal polypeptide

Tachykinin 1

Insulin-like growth factor-binding protein-5

Ectonucleotide pyrophosphatase/phosphodiesterase 2

Prolactin receptor

Complement component 3

Gastrin-releasing peptide
$6 \cdot 1$

$2 \cdot 2$

$2 \cdot 1$

$2 \cdot 1$

$2 \cdot 1$

$2 \cdot 1$

$1 \cdot 7$

$1 \cdot 7$

$1 \cdot 6$

$1 \cdot 6$

$1 \cdot 5$

$7 \cdot 5$

$3 \cdot 7$

$2 \cdot 9$

$2 \cdot 9$

$2 \cdot 7$

$2 \cdot 6$

$2 \cdot 6$

$2 \cdot 5$

$2 \cdot 3$

$2 \cdot 3$

$2 \cdot 2$

$2 \cdot 1$

$2 \cdot 1$

$2 \cdot 0$

$1 \cdot 7$

$1 \cdot 7$

$1 \cdot 7$

$1 \cdot 6$

$1 \cdot 6$

$1 \cdot 6$

$1 \cdot 6$

$1 \cdot 6$

$1 \cdot 6$

$1 \cdot 5$

$-1 \cdot 5$

$P$ value

$<0 \cdot 0005$

$<0 \cdot 0005$

$<0.0005$

$0 \cdot 002$

$<0 \cdot 0005$

$<0 \cdot 0005$

$<0 \cdot 0005$

$<0.0005$

0.002

0.001

$<0.0005$

$<0.0005$

$<0.0005$

0.003

$<0.0005$

$<0.0005$

0.0001

0.003

0.002

$<0.0005$

$<0.0005$

$<0.0005$

$<0.0005$

0.002

$0 \cdot 001$

$<0.0005$

$<0.0005$

$<0.0005$

$<0.0005$

$<0.0005$

$<0.0005$

$<0.0005$

$<0.0005$

$0 \cdot 001$

$<0.0005$

0.0003

$<0.0005$

$0 \cdot 0001$

0.003

$0 \cdot 0008$

0.003

$<0.0005$

$<0.0005$

0.0002

$<0.0005$

0.0002

$<0.0005$

$<0.0005$

$<0 \cdot 0005$

$12 \cdot 8<0 \cdot 0005$

$3.7<0.0005$

$2.9 \quad 0.002$

$2 \cdot 6<0 \cdot 0005$

$2 \cdot 5<0.0005$

$2 \cdot 3<0.0005$

$2 \cdot 2<0.0005$

$2 \cdot 1<0.0005$

$2 \cdot 1 \quad 0 \cdot 001$

(continued) 
Table 1 Continued

\begin{tabular}{|c|c|c|c|}
\hline Genes & Description & Fold & $P$ value \\
\hline Cartpt & CART prepropeptide & $2 \cdot 1$ & $<0 \cdot 0005$ \\
\hline Slc6a8 & $\begin{array}{l}\text { Solute carrier family } 6 \text { (neurotransmitter transporter, creatine), } \\
\text { member } 8\end{array}$ & $1 \cdot 8$ & $<0 \cdot 0005$ \\
\hline Apobec1 & Apolipoprotein B editing complex 1 & $1 \cdot 7$ & $0 \cdot 0003$ \\
\hline$H b a-\alpha 1$ & Hemoglobin alpha, adult chain 1 & $1 \cdot 6$ & $0 \cdot 0008$ \\
\hline$H b b-\beta 1$ & Hemoglobin, beta adult major chain & $1 \cdot 6$ & $<0 \cdot 0005$ \\
\hline Lpl & Lipoprotein lipase & $-1 \cdot 5$ & $<0 \cdot 0005$ \\
\hline Pcsk9 & Proprotein convertase subtilisin/kexin type 9 & $-1 \cdot 5$ & $0 \cdot 0001$ \\
\hline Adh1 & Alcohol dehydrogenase 1 (class I) & $-1 \cdot 7$ & $0 \cdot 0002$ \\
\hline lbsp & Integrin-binding sialoprotein & $-1 \cdot 7$ & $0 \cdot 002$ \\
\hline \multicolumn{4}{|l|}{ Cell death } \\
\hline Sftpd & Surfactant-associated protein D & $12 \cdot 8$ & $<0 \cdot 0005$ \\
\hline Tnfrsf11 $\mathrm{b}$ & Osteoprotegerin & $3 \cdot 7$ & $<0 \cdot 0005$ \\
\hline Vip & Vasoactive intestinal polypeptide & $2 \cdot 9$ & $0 \cdot 002$ \\
\hline Nupr1 & Nuclear protein 1 & $2 \cdot 9$ & $0 \cdot 001$ \\
\hline Tac1 & Tachykinin 1 & $2 \cdot 6$ & $<0 \cdot 0005$ \\
\hline Socs2 & Suppressor of cytokine signaling 2 & $2 \cdot 6$ & $<0 \cdot 0005$ \\
\hline lgfbp-5 & Insulin-like growth factor-binding protein-5 & $2 \cdot 5$ & $<0 \cdot 0005$ \\
\hline Prlr & Prolactin receptor & $2 \cdot 2$ & $<0 \cdot 0005$ \\
\hline C3 & Complement component 3 & $2 \cdot 1$ & $<0 \cdot 0005$ \\
\hline Gadd $45 \alpha$ & Growth arrest and DNA-damage-inducible 45 alpha & $2 \cdot 0$ & $<0 \cdot 0005$ \\
\hline$D n m t 3 b$ & DNA methyltransferase $3 \mathrm{~B}$ & $1 \cdot 7$ & $<0 \cdot 0005$ \\
\hline C1qa & Complement component 1 , g subcomponent, alpha polypeptide & $1 \cdot 7$ & $<0 \cdot 0005$ \\
\hline $\mathrm{Fg} / 2$ & Fibrinogen-like protein 2 & $1 \cdot 6$ & $<0 \cdot 0005$ \\
\hline Fhit & Fragile histidine triad gene & $1 \cdot 6$ & $<0 \cdot 0005$ \\
\hline Ptpre & Protein tyrosine phosphatase, receptor type, E & $1 \cdot 6$ & $0 \cdot 003$ \\
\hline Ezr & Ezrin & $1 \cdot 6$ & $<0 \cdot 0005$ \\
\hline Ern1 & Endoplasmic reticulum (ER) to nucleus signaling 1 & $1 \cdot 6$ & $0 \cdot 0003$ \\
\hline Eif4ebp1 & Eukaryotic translation initiation factor $4 \mathrm{E}$ binding protein 1 & $1 \cdot 6$ & $0 \cdot 003$ \\
\hline Ntrk2 & Neurotrophic tyrosine kinase, receptor, type 2 & $1 \cdot 5$ & $<0 \cdot 0005$ \\
\hline Pcsk9 & Proprotein convertase subtilisin/kexin type 9 & $-1 \cdot 5$ & $0 \cdot 0001$ \\
\hline Defb1 & Defensin beta 1 & $-1 \cdot 5$ & $0 \cdot 0002$ \\
\hline Anpep & Alanyl (membrane) aminopeptidase & $-1 \cdot 5$ & $<0 \cdot 0005$ \\
\hline Fosb & FBJ osteosarcoma oncogene B & $-1 \cdot 5$ & $<0 \cdot 0005$ \\
\hline \multicolumn{4}{|c|}{ Cellular movement } \\
\hline Sftpd & Surfactant-associated protein D & $12 \cdot 8$ & $<0 \cdot 0005$ \\
\hline Tnfrsf $11 b$ & Osteoprotegerin & $3 \cdot 7$ & $<0 \cdot 0005$ \\
\hline Vip & Vasoactive intestinal polypeptide & $2 \cdot 9$ & $0 \cdot 002$ \\
\hline Tac1 & Tachykinin 1 & $2 \cdot 6$ & $<0 \cdot 0005$ \\
\hline Socs2 & Suppressor of cytokine signaling 2 & $2 \cdot 6$ & $<0 \cdot 0005$ \\
\hline Enpp2 & Ectonucleotide pyrophosphatase/phosphodiesterase 2 & $2 \cdot 3$ & $<0 \cdot 0005$ \\
\hline Cartpt & CART prepropeptide & $2 \cdot 1$ & $<0 \cdot 0005$ \\
\hline Grp & Gastrin-releasing peptide & $2 \cdot 1$ & $0 \cdot 001$ \\
\hline C3 & Complement component 3 & $2 \cdot 1$ & $<0 \cdot 0005$ \\
\hline Gadd $45 \alpha$ & Growth arrest and DNA-damage-inducible 45 alpha & $2 \cdot 0$ & $<0 \cdot 0005$ \\
\hline$D n m t 3 b$ & DNA methyltransferase 3B & $1 \cdot 7$ & $<0 \cdot 0005$ \\
\hline Ezr & Ezrin & $1 \cdot 6$ & $<0 \cdot 0005$ \\
\hline $\mathrm{Fg} / 2$ & Fibrinogen-like protein 2 & $1 \cdot 6$ & $<0.0005$ \\
\hline Fhit & Fragile histidine triad gene & $1 \cdot 6$ & $<0 \cdot 0005$ \\
\hline Ntrk2 & Neurotrophic tyrosine kinase, receptor, type 2 & $1 \cdot 5$ & $<0 \cdot 0005$ \\
\hline Defb1 & Defensin beta 1 & $-1 \cdot 5$ & $0 \cdot 0002$ \\
\hline Anpep & Alanyl (membrane) aminopeptidase & $-1 \cdot 5$ & $<0 \cdot 0005$ \\
\hline Rap2a & RAS-related protein $2 \mathrm{a}$ & $-1 \cdot 6$ & $0 \cdot 003$ \\
\hline \multicolumn{4}{|c|}{ Metabolism } \\
\hline Tph2 & Tryptophan hydroxylase 2 & $3 \cdot 9$ & $<0 \cdot 0005$ \\
\hline Ivd & Isovaleryl coenzyme A dehydrogenase & $3 \cdot 7$ & $<0 \cdot 0005$ \\
\hline Tnfrsf1 $1 \mathrm{~b}$ & Osteoprotegerin & $3 \cdot 7$ & $<0 \cdot 0005$ \\
\hline Tac1 & Tachykinin 1 & $2 \cdot 6$ & $<0 \cdot 0005$ \\
\hline lgfbp-5 & Insulin-like growth factor-binding protein-5 & $2 \cdot 5$ & $<0 \cdot 0005$ \\
\hline Prlr & Prolactin receptor & $2 \cdot 2$ & $<0 \cdot 0005$ \\
\hline
\end{tabular}


Table 1 Continued

\begin{tabular}{|c|c|c|c|}
\hline Genes & Description & Fold & $P$ value \\
\hline Prlr & Prolactin receptor & $2 \cdot 2$ & $<0 \cdot 0005$ \\
\hline Grp & Gastrin-releasing peptide & $2 \cdot 1$ & $0 \cdot 001$ \\
\hline C3 & Complement component 3 & $2 \cdot 1$ & $<0 \cdot 0005$ \\
\hline Cartpt & CART prepropeptide & $2 \cdot 1$ & $<0 \cdot 0005$ \\
\hline Slc40a1 & Solute carrier family 40, member 1 & $2 \cdot 1$ & $<0 \cdot 0005$ \\
\hline Grh/1 & Grainyhead-like 1 (Drosophila) & $2 \cdot 0$ & $<0 \cdot 0005$ \\
\hline Slc2a13 & Solute carrier family 2 (facilitated glucose transporter), 13 & $2 \cdot 0$ & $<0 \cdot 0005$ \\
\hline Enox1 & Ecto-NOX disulfide-thiol exchanger 1 & $1 \cdot 8$ & $<0 \cdot 0005$ \\
\hline Slc6a8 & $\begin{array}{l}\text { Solute carrier family } 6 \text { (neurotransmitter transporter, creatine), } \\
\text { member } 8\end{array}$ & $1 \cdot 8$ & $<0 \cdot 0005$ \\
\hline$C d h 7$ & Cadherin 7 , type 2 & $1 \cdot 7$ & $<0 \cdot 0005$ \\
\hline Matn2 & Matrilin 2 & $1 \cdot 7$ & $<0 \cdot 0005$ \\
\hline Gcdh & Glutaryl-coenzyme A dehydrogenase & $1 \cdot 6$ & $<0 \cdot 0005$ \\
\hline Fhit & Fragile histidine triad gene & $1 \cdot 6$ & $<0 \cdot 0005$ \\
\hline Ptpre & Protein tyrosine phosphatase, receptor type, E & $1 \cdot 6$ & $0 \cdot 003$ \\
\hline Slc39a11 & Solute carrier family 39 (metal ion transporter), member 11 & $1 \cdot 6$ & $<0 \cdot 0005$ \\
\hline Uhrf2 & Ubiquitin-like, containing PHD and RING finger, 2 & $1 \cdot 6$ & $<0 \cdot 0005$ \\
\hline Ntrk2 & Neurotrophic tyrosine kinase, receptor, type 2 & $1 \cdot 5$ & $<0 \cdot 0005$ \\
\hline Atp8a1 & ATPase, aminophospholipid transporter & $1 \cdot 5$ & $<0 \cdot 0005$ \\
\hline Edem2 & ER degradation enhancer, mannosidase alpha-like 2 & $1 \cdot 5$ & $0 \cdot 0003$ \\
\hline Tmem2 & Transmembrane protein 2 & $1 \cdot 5$ & $<0 \cdot 0005$ \\
\hline Lpl & Lipoprotein lipase & $-1 \cdot 5$ & $<0 \cdot 0005$ \\
\hline Pcsk9 & Proprotein convertase subtilisin/kexin type 9 & $-1 \cdot 5$ & $0 \cdot 0001$ \\
\hline Neurog3 & Neurogenin 3 & $-1 \cdot 5$ & $<0 \cdot 0005$ \\
\hline Tox & Thymocyte selection-associated high-mobility group box & $-1 \cdot 5$ & $<0 \cdot 0005$ \\
\hline$D d c$ & DOPA decarboxylase & $-1 \cdot 6$ & $<0 \cdot 0005$ \\
\hline Hmgn3 & High-mobility group nucleosomal-binding domain 3 & $-1 \cdot 6$ & $<0 \cdot 0005$ \\
\hline Scg3 & Secretogranin III & $-1 \cdot 6$ & $<0 \cdot 0005$ \\
\hline \multicolumn{4}{|c|}{ Inflammation } \\
\hline Sftpd & Surfactant-associated protein D & $12 \cdot 8$ & $<0 \cdot 0005$ \\
\hline Tph2 & Tryptophan hydroxylase 2 & $3 \cdot 9$ & $<0.0005$ \\
\hline Tnfrsf $11 b$ & Osteoprotegerin & $3 \cdot 7$ & $<0.0005$ \\
\hline Chgb & Chromogranin B & $2 \cdot 9$ & $<0 \cdot 0005$ \\
\hline Tac1 & Tachykinin 1 & $2 \cdot 6$ & $<0 \cdot 0005$ \\
\hline Hopx & HOP homeobox & $2 \cdot 3$ & $<0 \cdot 0005$ \\
\hline Enpp2 & Ectonucleotide pyrophosphatase/phosphodiesterase 2 & $2 \cdot 3$ & $<0 \cdot 0005$ \\
\hline Prlr & Prolactin receptor & $2 \cdot 2$ & $<0 \cdot 0005$ \\
\hline C3 & Complement component 3 & $2 \cdot 1$ & $<0 \cdot 0005$ \\
\hline Grp & Gastrin-releasing peptide & $2 \cdot 1$ & $0 \cdot 001$ \\
\hline Slc2a13 & Solute carrier family 2 (facilitated glucose transporter), 13 & $2 \cdot 0$ & $<0 \cdot 0005$ \\
\hline Sgip1 & SH3-domain GRB2-like (endophilin) interacting protein 1 & $2 \cdot 0$ & $<0 \cdot 0005$ \\
\hline Gadd $45 \alpha$ & Growth arrest and DNA-damage-inducible 45 alpha & $2 \cdot 0$ & $<0 \cdot 0005$ \\
\hline Enox1 & Ecto-NOX disulfide-thiol exchanger 1 & $1 \cdot 8$ & $<0 \cdot 0005$ \\
\hline C1qa & Complement component 1 , q subcomponent, alpha polypeptide & $1 \cdot 7$ & $<0 \cdot 0005$ \\
\hline Matn2 & Matrilin 2 & $1 \cdot 7$ & $<0 \cdot 0005$ \\
\hline$H b a-\alpha 1$ & Hemoglobin alpha, adult chain 1 & $1 \cdot 6$ & $0 \cdot 0008$ \\
\hline$H b b-\beta 1$ & Hemoglobin, beta adult major chain & $1 \cdot 6$ & $<0 \cdot 0005$ \\
\hline Slc39a11 & Solute carrier family 39 (metal ion transporter), member 11 & $1 \cdot 6$ & $<0 \cdot 0005$ \\
\hline Fhit & Fragile histidine triad gene & $1 \cdot 6$ & $<0 \cdot 0005$ \\
\hline Ern1 & Endoplasmic reticulum (ER) to nucleus signaling 1 & $1 \cdot 6$ & $0 \cdot 0003$ \\
\hline Atp8a1 & ATPase, aminophospholipid transporter & $1 \cdot 5$ & $<0 \cdot 0005$ \\
\hline Tspan14 & Tetraspanin 14 & $1 \cdot 5$ & $<0 \cdot 0005$ \\
\hline Ntrk2 & Neurotrophic tyrosine kinase, receptor, type 2 & $1 \cdot 5$ & $<0 \cdot 0005$ \\
\hline Edem2 & ER degradation enhancer, mannosidase alpha-like 2 & $1 \cdot 5$ & $0 \cdot 0003$ \\
\hline Tox & Thymocyte selection-associated high-mobility group box & $-1 \cdot 5$ & $<0 \cdot 0005$ \\
\hline Anpep & Alanyl (membrane) aminopeptidase & $-1 \cdot 5$ & $<0 \cdot 0005$ \\
\hline Fosb & FBJ osteosarcoma oncogene B & $-1 \cdot 5$ & $<0 \cdot 0005$ \\
\hline Acpl2 & Acid phosphatase-like 2 & $-1 \cdot 6$ & $<0 \cdot 0005$ \\
\hline Sphkap & SPHK1 interactor, AKAP domain containing & $-1 \cdot 6$ & $0 \cdot 0005$ \\
\hline$D d c$ & DOPA decarboxylase & $-1 \cdot 6$ & $<0 \cdot 0005$ \\
\hline Aard & Alanine and arginine-rich domain-containing protein & $-1 \cdot 7$ & $<0 \cdot 0005$ \\
\hline
\end{tabular}


Table 1 Continued

\begin{tabular}{|c|c|c|c|}
\hline Genes & Description & Fold & $P$ value \\
\hline \multicolumn{4}{|c|}{ Miscellaneous } \\
\hline Fmo1 & Flavin-containing monooxygenase 1 & $10 \cdot 7$ & $<0 \cdot 0005$ \\
\hline B3galnt1 & UDP-beta 1, 3-galactosaminyltransferase, polypep-1 & $2 \cdot 9$ & $0 \cdot 001$ \\
\hline$E G 244911$ & Predicted gene, EG244911 & $2 \cdot 8$ & $<0 \cdot 0005$ \\
\hline H21Rik & RIKEN cDNA $6430550 \mathrm{H} 21$ gene & $2 \cdot 8$ & $<0 \cdot 0005$ \\
\hline Hsbp-1 & Heat shock factor-binding protein-1 & $2 \cdot 7$ & $0 \cdot 0007$ \\
\hline Wipi1 & WD repeat domain, phosphoinositide interacting 1 & $2 \cdot 6$ & $<0.0005$ \\
\hline Znrf2 & Zinc and ring finger 2 & $2 \cdot 4$ & $0 \cdot 0009$ \\
\hline Car15 & Carbonic anhydrase 15 & $2 \cdot 4$ & $0 \cdot 003$ \\
\hline Chac1 & ChaC, cation transport regulator-like 1 (Escherichia coli) & $2 \cdot 2$ & $0 \cdot 002$ \\
\hline Aqp4 & Aquaporin 4 & $2 \cdot 2$ & $0 \cdot 0009$ \\
\hline Txnrd2 & Thioredoxin reductase 2 & $2 \cdot 0$ & $<0 \cdot 0005$ \\
\hline Fkbp-11 & FK506-binding protein-11 & $2 \cdot 0$ & $0 \cdot 001$ \\
\hline Ehhadh & Enoyl-Coenzyme A, hydratase/3-hydroxyacyl CoA dehydrogenase & $1 \cdot 9$ & $<0 \cdot 0005$ \\
\hline lgfals & Insulin-like growth factor-binding protein, acid labile subunit & $1 \cdot 9$ & $0 \cdot 0005$ \\
\hline Rag1ap1 & Recombination activating gene 1 activating protein 1 & $1 \cdot 9$ & $0 \cdot 02$ \\
\hline Aldh1/2 & Aldehyde dehydrogenase 1 family, member L2 & $1 \cdot 9$ & $0 \cdot 002$ \\
\hline Pycr1 & Pyrroline-5-carboxylate reductase 1 & $1 \cdot 8$ & $0 \cdot 001$ \\
\hline$B C 006662$ & CDNA sequence BC006662 & $1 \cdot 7$ & $0 \cdot 0005$ \\
\hline Cldn8 & Claudin 8 & $1 \cdot 7$ & $0 \cdot 0005$ \\
\hline $\operatorname{Gn} \beta 11$ & G-protein, beta polypeptide 1 -like & $1 \cdot 7$ & $0 \cdot 0009$ \\
\hline Rnf182 & Ring finger protein 182 & $1 \cdot 7$ & $0 \cdot 001$ \\
\hline Hapln4 & Hyaluronan and proteoglycan link protein 4 & $1 \cdot 7$ & $0 \cdot 006$ \\
\hline Tmem28 & Transmembrane protein 28 & $1 \cdot 7$ & $0 \cdot 006$ \\
\hline Lsm6 & LSM6 homolog, U6 small nuclear RNA associated & $1 \cdot 6$ & $<0 \cdot 0005$ \\
\hline Ugt1a7c & UDP glucuronosyltransferase 1 family, polypeptide A7C & $1 \cdot 6$ & $0 \cdot 006$ \\
\hline Ugt1a6b & UDP glucuronosyltransferase 1 family, polypeptide A6B & $1 \cdot 5$ & $0 \cdot 001$ \\
\hline Edem1 & ER degradation enhancer, mannosidase alpha-like 1 & $1 \cdot 5$ & $0 \cdot 002$ \\
\hline Uck2 & Uridine-cytidine kinase 2 & $1 \cdot 5$ & $0 \cdot 01$ \\
\hline Do1Rik & RIKEN cDNA 22104 12D01 gene & $-1 \cdot 5$ & $0 \cdot 002$ \\
\hline$H 3 f 3 b$ & $\mathrm{H} 3$ histone, family $3 \mathrm{~B}$ & $-1 \cdot 5$ & $0 \cdot 04$ \\
\hline Mlxipl & MLX interacting protein-like & $-1 \cdot 5$ & $0 \cdot 001$ \\
\hline Slc30a8 & Solute carrier family 30 (zinc transporter), member 8 & $-1 \cdot 5$ & $0 \cdot 0006$ \\
\hline$M d m 1$ & Transformed mouse $3 \mathrm{~T} 3$ cell double minute 1 & $-1 \cdot 5$ & $<0 \cdot 0005$ \\
\hline Slc $29 a 4$ & Solute carrier family 29 (nucleoside transporters), member 4 & $-1 \cdot 6$ & $0 \cdot 001$ \\
\hline$N t 5 d c 2$ & $5^{\prime}$-nucleotidase domain-containing 2 & $-1 \cdot 7$ & $0 \cdot 02$ \\
\hline Sult1d1 & Sulfotransferase family $1 \mathrm{D}$, member 1 & $-1 \cdot 7$ & $0 \cdot 01$ \\
\hline Msx3 & Homeobox, msh-like 3 & $-1 \cdot 8$ & $0 \cdot 04$ \\
\hline Cib-3 & Calcium and integrin-binding family member-3 & $-1 \cdot 8$ & $0 \cdot 01$ \\
\hline CryßA2 & Crystallin, beta A2 & $-1 \cdot 8$ & $0 \cdot 0009$ \\
\hline
\end{tabular}

ashown are the 110 unique total transcripts that were identified, where each of these genes demonstrated at least $1 \cdot 5$-fold change, being statistically significant $(P$ value $<0 \cdot 01)$ with false discovery rate $(P<0 \cdot 05)$. These 110 genes were categorized based on a classification scheme from ingenuity, and could be classified into more than one category. The miscellaneous category corresponds to genes that did not appear in any category shown here.

\section{Cytokine treatment}

For studies with murine islets, purified islets were incubated for $24 \mathrm{~h}$ in RPMI 1640 (ATCC, Manassas, VA, USA) supplemented with $1 \%$ nonheat inactivated FBS. The medium was supplemented with or without $5 \mathrm{ng} / \mathrm{ml}$ interleukin $1 \beta$ (IL1 $\beta$ ) or $10 \mathrm{ng} / \mathrm{ml}$ tumor necrosis factor- $\alpha$ (TNF- $\alpha$, R\&D Systems, Minneapolis, MN, USA), and RNA was isolated as described above. Three independent experiments were performed.

\section{Statistical analysis}

$P$ values were calculated by Student's $t$-test (one tailed) with a significance level at $P<0 \cdot 05$ using Excel software. To determine the statistical significance for a change in the real-time RT-PCR studies, the fold change was used relative to the control condition, which was set at $1 \cdot 0$. For TPH1, statistical analysis was performed using logarithmic transformed values.

\section{Results}

Global RNA expression analysis of mouse islets during pregnancy

Pregnancy-induced changes in islet gene expression were examined by RNA expression analysis using RNA prepared from islets isolated from pregnant (day 13.5) and control 
(age- and sex-matched) mice. In all, 110 differentially expressed transcripts were identified (Fig. 1A), as defined by a statistically significant $(P<0 \cdot 01$, FDR $<5 \%)>1 \cdot 5$-fold change in expression. Table 1 lists the 110 differentially regulated transcripts using a classification scheme from ingenuity (see Materials and Methods). In Fig. 1B, these 110 differentially regulated genes are categorized into seven groups. An overrepresentation $P$ test, which is a hypergeometric test and provides a representation of the enrichment of the genes in each category compared with the chip as a whole, demonstrated that the genes in each of the categories were overrepresented relative to the genes on the chip as a whole.

To confirm the results of the RNA expression analysis, real-time RT-PCR was performed on a select group of the differentially regulated genes (rationale for their selection is provided below). The gene encoding SP-D was examined as it demonstrated the greatest pregnancy-induced change in expression in the global expression array $(12 \cdot 8$-fold increase in SP-D mRNA levels). This finding was verified by real-time RT-PCR (Fig. 2A) where the level of SP-D mRNA increased $22 \cdot 4 \pm 1 \cdot 7$-fold (mean \pm s.E.M., $n=3, P<0 \cdot 05$ ) in pregnant compared with that in control islets. Real-time RT-PCR studies were performed on additional genes that demonstrated significant pregnancy-induced increases in mRNA levels and have been directly or indirectly implicated in islet function: osteoprotegrin (Schrader et al. 2007), TPH1 (Paulmann et al. 2009), TPH2 (Paulmann et al. 2009), cytokine-inducible SH2-containing protein (Dif et al. 2001), and isovaleryl-CoA dehydrogenase (MacDonald 2007). The pregnancy-induced changes in the expression were confirmed for each of these genes (Fig. 2A). In addition, the expression of two ligands for GPCRs, gastrin-releasing peptide (GRP), and vasoactive intestinal polypeptide (VIP) was increased; however, in follow-up real-time RT-PCR analyses, the changes in GRP and VIP mRNA levels, while trending in the same direction, did not reach statistical significance (Fig. 2A). In addition to the above mRNAs, the levels of mRNA encoding the PRLR, which has a well described role in $\beta$ cells during pregnancy, as well as suppressor of cytokine signaling 2, which is known to attenuate PRLR signaling (Sutherland et al. 2007), were also increased by pregnancy in the global expression analysis and confirmed in real-time RT-PCR studies.

Among the mRNAs with a decreased level of expression in pregnant compared with that in control islets were mRNAs encoding zinc transporter-8 (ZnT8), neurogenin 3 (NGN3), and MLX interacting protein-like 1 (Mlxipl). ZnT8 and NGN3 are important for islet cell function and/or development ( $\mathrm{Gu}$ et al. 2002, Lemaire et al. 2009), while the role of Mlxip1 in islets is unclear, although an association with NGN3 has been reported (Soyer et al. 2010). The pregnancy-induced changes in the expression for each of these genes were confirmed by real-time RT-PCR (Fig. 2B).

Figure 2C shows the results of western blot analyses that examined changes in the protein level of select genes in islets from pregnant mice compared with those in control mice.
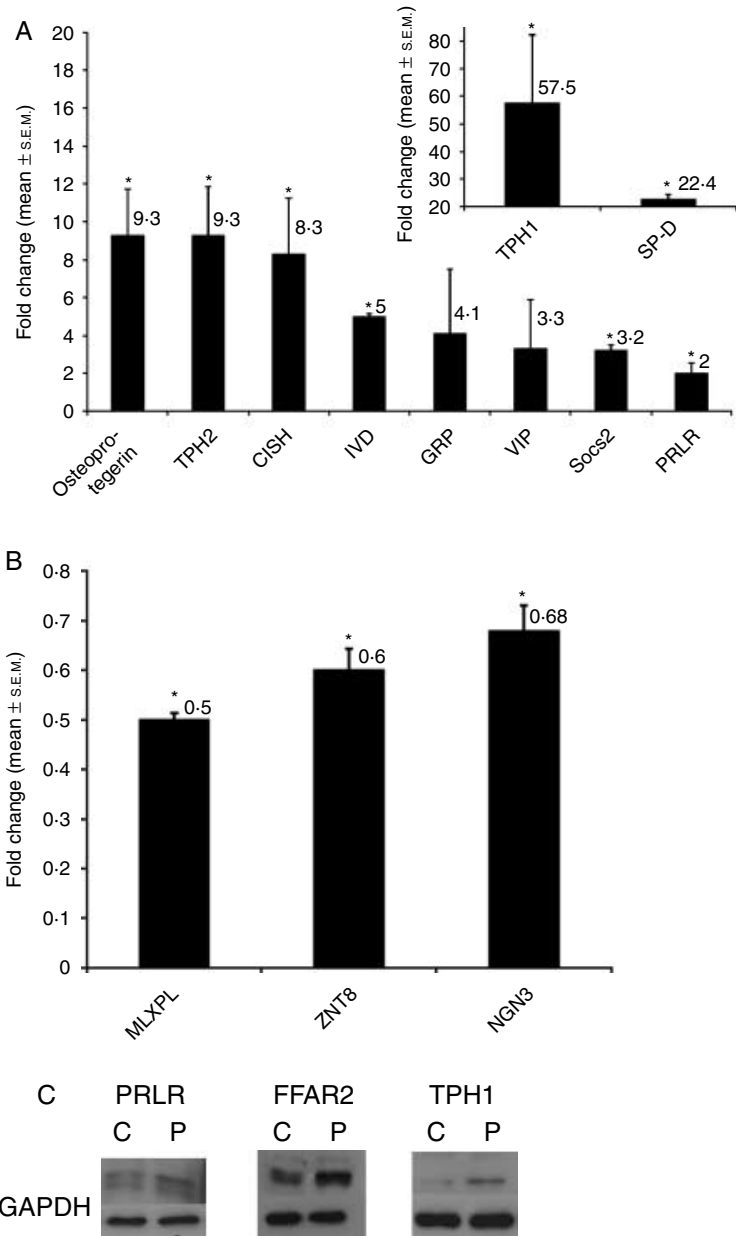

Figure 2 Pregnancy induced changes in expression of select genes by real-time RT-PCR and western blot analysis. (A and B) Fold change in the level of select mRNAs in islets isolated from pregnant mice at day E13.5 compared with that in age- and sex-matched control mice. (A) Shows the results for genes with increased mRNA levels and (B) shows the results for genes with deceased mRNA levels in pregnant compared with the control islets. The change in the level of each of the transcripts in both $(A)$ and $(B)$ was statistically significant at $P<0 \cdot 05$ (indicated by ${ }^{*}$ ), except for GRP $(P=0 \cdot 13)$ and VIP $(P=0 \cdot 13)$. Values are the mean fold change \pm s.E.M. from three independently prepared samples (each individual sample was a pooled sample from three mice). Fold change was calculated by a comparative cycle time $\left(C_{\mathrm{t}}\right)$ approach (see Materials and Methods) where the housekeeping genes (HPRT, TBP, and PPIA) were determined by geNORM (Vandesompele et al. 2002) using an approach defined in section 'Materials and Methods'. The housekeeping $C_{\mathrm{t}} \mathrm{s}$ were used to derive the geometric means for the comparative $C_{\mathrm{t}}$ analyses. (C) Changes in the level of proteins encoded by three genes that exhibited pregnancy-induced changes in expression. Proteins were extracted from isolated islets from pregnant mice at day E13.5 and age- and sex-matched control mice. Representative immunoblots for prolactin receptor (PRLR), FFAR2, and TPH1 are shown. Shown are the results of a single experiment. Three independent experiments were performed. Each experiment was performed using islets prepared from a different control and pregnant mouse. After hybridization, the blots were stripped and re-probed with antibody against GAPDH. 
The expression of each of the proteins was increased in pregnant compared with that in control islets, consistent with the pregnancy-induced change in the level of their mRNA.

\section{A potential role of SP-D in pancreatic $\beta$ cells}

The transcript encoding SP-D exhibited the largest pregnancy-induced increase in expression in the global expression analysis, which was confirmed by the real-time RT-PCR studies. As the expression of SP-D in adult islets has not been observed before, we examined SP-D expression in islets during pregnancy. Using mouse monoclonal antibodies, SP-D was detected in the mouse lung tissue (Fig. 3A, lane 2, at $\sim 40-45 \mathrm{kDa}$ ) but not in the brain (lane 1), consistent with the known pattern of SP-D expression (Motwani et al. 1995). The immunoreactive SP-D detected in mouse lung was consistent with monomeric SP-D, which is $\sim 45 \mathrm{kDa}$ (Sørensen et al. 2009). However, SP-D is commonly present in large complex structures (Sørensen et al. 2009). In unreduced preparations, the antibody typically recognizes proteins with a molecular weight of $\sim 120 \mathrm{kDa}$ and above, which likely represent trimers and other multimers. In our studies, using unreduced protein preparations, the anti-SP-D antibodies recognized proteins of $\sim 120$ and $180 \mathrm{kDa}$ (see Fig. 3A, lane 3) consistent with previous reports (Sørensen et al. 2009). Interestingly, in murine islets, a single band of $\sim 100 \mathrm{kDa}$ was detected and in the nonreduced state, a band of $\sim 180 \mathrm{kDa}$ was observed (Fig. 3A, lanes 4 and 5). It has been previously described that differences in covalent binding patterns between SP-D monomers exist and can result in the formation of nonreducible dimers (Crouch et al. 1993, Guo et al. 2008, Matalon et al. 2009, Sørensen et al. 2009) that are detected by western blots. Therefore, this band at $100 \mathrm{kDa}$ likely represents a dimer. To further explore this, we examined SP-D expression in the lung, pancreas, spleen, and islets (Fig. 3A, lanes 6-9). All tissues exhibited immunoreactive bands at both 45 and $100 \mathrm{kDa}$, although the relative intensities of the bands varied widely between tissues. These data are consistent with differences in SP-D complexes between the tissues. Finally, we compared the level of SP-D in islets from control and pregnant mice, and found increased expression in pregnant islets, consistent with the pregnancy-induced increase in the level of SP-D mRNA (Fig. 3B).

In addition to its role in surfactant biology, SP-D may have an anti-inflammatory role in the lung tissue (Sørensen et al. 2007). As pregnancy is characterized by increased levels of pro-inflammatory peptides (Richardson \& Carpenter 2007), we hypothesized that SP-D mRNA levels may be regulated by pro-inflammatory molecules in islets. To address this possibility, the impact of treating isolated native murine islets for $48 \mathrm{~h}$ with IL1 $\beta$ or TNF- $\alpha$ on SP-D expression was examined. As can be seen (Fig. 3C), IL1 $\beta$ and TNF- $\alpha$ each increased SP-D mRNA levels in isolated murine islets.
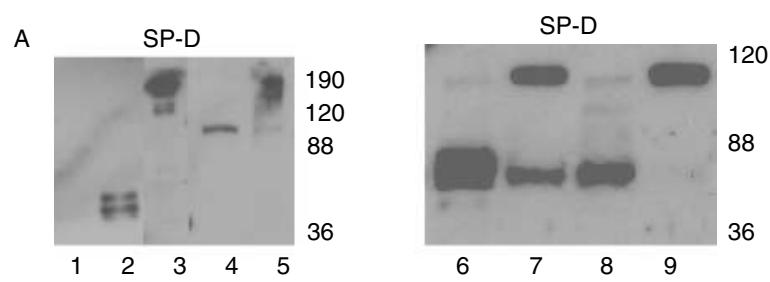

B

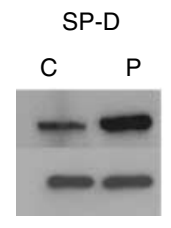

GAPDH

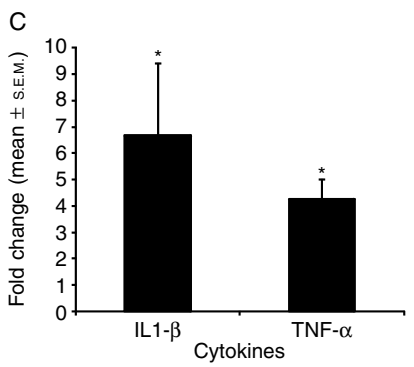

Figure 3 Surfactant protein D (SP-D) expression in mouse islets. (A) Expression of SP-D in the lungs and islets. Proteins were extracted from mouse lung and islets. Samples from the brain (lane 1), lung (lane 2), mouse lung - not reduced (lane 3), islets (lane 4), islets - not reduced (lane 5), lung (lane 6), pancreas (lane 7), spleen (lane 8), and islets (lane 9) were either reduced or not reduced prior to separation by PAGE. The results are representative of the results of two to three independent experiments. (B) SP-D expression in pregnant islets. Protein extracts were prepared from islets isolated from pregnant mice at day E13.5 and age- and sex-matched control mice. Western blot analysis was performed as described in section 'Materials and Methods.' C, control; P, pregnant. After hybridization, the blots were stripped and re-probed with antibody against $\mathrm{GAPDH}$. The findings are representative of the results of three independent experiments. (C) Effect of cytokines on SP-D mRNA levels in murine islets. RNA was prepared from murine islets treated for $48 \mathrm{~h}$ with $5 \mathrm{ng} / \mathrm{ml} \mathrm{IL} 1 \beta$ or $10 \mathrm{ng} / \mathrm{ml} \mathrm{TNF}-\alpha$. The fold change in SP-D mRNA was determined by real-time RT-PCR, using the comparative method and the housekeeping gene, 185 . Values represent the mean \pm s.E.M. (three independent samples, $n=3$ ) and are the relative level of SP-D mRNA compared with the level in control islets not treated with cytokines. ${ }^{*} P<0 \cdot 05$ compared with control mice.

\section{Analysis of GPCR-specific expression in mouse islets during pregnancy}

In the global RNA expression analysis, one GPCR, FFAR2, was differentially regulated by pregnancy $(>1 \cdot 5$-fold change in expression, $P<0 \cdot 01)$. As the genes for GPCRs tend to be underrepresented in the global RNA expression analyses, potentially leading to missed targets (Fredriksson \& Schioth 2005), further studies were performed to determine whether pregnancy induced changes in the expression of genes encoding members of this receptor family. To do this, a secondary approach, a real-time RT-PCR array, was used to examine the expression of transcripts encoding 343 different GPCRs. The expression of GPCRs in the mouse islets during pregnancy at E13.5 was compared with the expression in islets isolated from nonpregnant female mice. Of the 343 GPCRs probed in the real-time array, the mRNAs encoding 216 of these GPCRs were detectable in the islets, as defined by the 
detection of a discernible melt curve in the control islets. Of the 343 GPCR transcripts that were examined in the realtime RT-PCR array, 92 were detected in the global RNA expression array. For this study, we focused on the 100 most highly expressed GPCR mRNAs in control islets (Table 2). Three of these GPCRs (FFAR2; GAL3R, galanin receptor 3; and CCKAR, cholecystokinin receptor A) exhibited a $>2.5$-fold change in the expression in pregnant compared with those in control islets. In the global RNA expression analysis, the mRNA encoding CCKAR was not detected. In contrast, FFAR 2 mRNA exhibited a significant $1 \cdot 5$-fold increase in expression in the global RNA expression analysis and GAL3R mRNA was increased 1.3-fold $(P=0 \cdot 19)$. Follow-up real-time RT-PCR studies of these three GPCRs were performed (Fig. 4), and a significant pregnancy-induced increase in mRNA levels was observed for only FFAR 2 and CCKAR $(P<0 \cdot 05)$.

\section{Discussion}

The global RNA expression analysis and the confirmatory real-time RT-PCR assays demonstrated a marked increase in the level of the mRNA encoding SP-D, a protein best known for its role in lung function (Botas et al. 1998). A clear role for SP-D in lung and surfactant homeostasis has been described (Sørensen et al. 2007), but expression of this gene in the adult islets has not been previously reported. However, a recent study identified SP-D as a marker of new $\beta$ cell formation during the perinatal period (Aye et al. 2010). A global SP-D knockout has been created (Botas et al. 1998), although alterations in glucose metabolism and/or islet biology in these mice have not been reported. A possible metabolic role of SP-D is suggested by the observation that SP-D impacts systemic lipid levels and atherosclerosis (Sørensen et al. 2006b). Consistent with that is the observation that circulating SP-D levels are inversely associated with obesity in humans (Zhao et al. 2007). Furthermore, mice with a null mutation of the SP-D gene maintained on a normal diet exhibited more weight gain and increased adiposity compared with control mice (Sørensen et al. 2006a).

The novel observation that SP-D mRNA is expressed in $\beta$ cells was confirmed by western blot and immunohistochemical analyses (see Fig. 3A and B). Through a combination of studies, it is apparent that SP-D in islets exists in a form that leads to nonreducible dimers. This is not surprising, considering the complex nature of this protein. First, SP-D ranges in size from 37 to $50 \mathrm{kDa}$ in the monomeric form because of different glycosylation patterns (Leth-Larsen et al. 1999, Sørensen et al. 2009). Furthermore, SP-D trimers contain multiple disulfide bonds between cysteine residues as well as nondisulfide covalent bonds, and these nondisulfide covalent bonds result in dimers resistant to reduction (Crouch et al. 1993, Guo et al. 2008, Matalon et al. 2009, Sørensen et al. 2009). As the function of SP-D is dependent on these modifications (Leth-Larsen et al. 1999, Sørensen et al. 2009), the modifications of SP-D in islets may have important implications for its function.

If SP-D indeed has a role in islet function, it could be hypothesized that, similar to endothelial cells where SP-D has an anti-inflammatory role (Snyder et al. 2008), it may function as an anti-inflammatory molecule in islets. As pregnancy is characterized by increased levels of circulating pro-inflammatory molecules (Richardson \& Carpenter 2007), we examined the impact of the pro-inflammatory cytokines, IL1 $\beta$ and TNF- $\alpha$, on SP-D expression in islets. We demonstrated that not only SP-D mRNA is expressed in islets but also its expression is regulated by cytokines. This is consistent with the possibility that SP-D serves as an antiinflammatory factor in islets during pregnancy, although future studies will be needed to more fully examine this possibility. As with another anti-inflammatory molecule, cytokine IL1 receptor antagonist, which protects mice fed with high-fat diets from hyperglycemia (Sauter et al. 2008), this type of molecule could have unique therapeutic potential.

Recent genome-wide association studies have reported association of a missense mutation in $S L C 30 \mathrm{~A} 8$, the gene that encodes the ZnT8, with type 2 diabetes (Chimienti et al. 2006, Sladek et al. 2007). ZnT8 may also be an autoantigen in type 1 diabetes (Wenzlau et al. 2007). Expression of SLC30A8 is largely localized to islets and, more specifically, $\beta$ cells (Chimienti et al. 2006). ZnT8 is thought to play an important role in zinc transport into the insulin secretory granules (Nicolson et al. 2009). Thus, the decrease in ZnT8 mRNA levels in islets from pregnant compared with those in control mice was unexpected given the increased insulin secretory demands in pregnancy. However, pregnancy is a pro-inflammatory state, and recent observations (Egefjord et al. 2009, El Muayed et al. 2010) have shown that cytokines decrease the level of ZnT8 mRNA in islet cells. This may explain, in part, the pregnancy-induced decrease in ZnT8 mRNA levels.

In addition to the global RNA expression analysis, we examined genes encoding the GPCRs in greater detail. Multiple GPCRs are known to be expressed in islets (Winzell \& Ahren 2007), but the impact of pregnancy on GPCR expression has not been previously examined. These receptors are well-known targets for multiple medicinal therapies. Moreover, given the important role of some GPCRs (e.g. the glucagon-like peptide 1 and parathyroid hormone-1 receptors) in the regulation of islet function and mass (De Leon et al. 2003), we explored the impact of pregnancy on the expression of mRNAs encoding GPCRs in islets using a realtime RT-PCR array. This array examined the level of mRNAs encoding 343 GPCRs in pregnant compared with that in control islets and was complementary to the global RNA expression analyses. Low levels of GPCR mRNA (Fredriksson \& Schioth 2005) and the stringent requirements for statistical significance can lead to missed targets with the global RNA expression analysis. A recent study reported a role for serotonin in the regulation of $\beta$ cell mass in pregnancy (Kim et al. 2010). The expression of mRNA encoding the serotonin 
Table 2 Comparison of the 100 most highly expressed G-protein-coupled receptors (GPCRs) in the GPCR-specific real-time reverse transcripton-PCR array compared with the global expression array for RNA from islets isolated from pregnant mice (E13.5) compared with control mice (age- and sex-matched)

GPCR array

$\underline{\text { Relative expression }^{a} \quad} \quad \underline{\text { Fold change }^{a}}$

\section{GPCRs}

Glp1r

Sstr3

Adra2a

Gabbr2

Gpr56

Gipr

Gpr116

Lphn1

Casr

Ffar1

Gpr108

Gpr119

Vipr1

Adora1

Gpr137b

Chrm3

Galr1

Gpr137

P2ry6

Crcp

F2rl1

P2ry5

Ptger3

Bai3

Tm7sf3

Eltd1

Gabbr1

Gcgr

Gprc5c

Lgr4

Adcyap1r1

Fzd4

Fzd3

Fzd6

Gpr125

Fzd7

Taar1

F2r

Edg2

Ednra

Lphn3

Ccrl2

Calcrl

Cd97

Gpr146

Chrm4

Fzd5

Gpr120

Oxtr

Celsr3

Ednrb

Gprc5b

Lphn2

Fzd8

Gpr85

Cnr1

Galr3

Gpr39
32988

11663

9473

5441

5441

5077

5077

5077

4737

4419

4419

4123

4123

2720

2683

2538

2368

2210

2062

1924

1795

1795

1360

1269

1269

1184

1184

1184

1184

1184

1105

1105

1031

1031

1031

962

962

897

837

837

837

729

680

680

680

635

635

635

635

592

592

592

592

552

552

515

515

515

\section{Global array}

${\text { Fold change }{ }^{\mathrm{a}} \quad P<\text { value }}$

$1 \cdot 7$

$1 \cdot 1$

$1 \cdot 1$

$2 \cdot 1$

$1 \cdot 4$

$1 \cdot 3$

$0 \cdot 6$

0.9

$0 \cdot 8$

$1 \cdot 1$

$1 \cdot 4$

$2 \cdot 0$

$0 \cdot 7$

0.7

0.9

$1 \cdot 3$

$1 \cdot 0$

$1 \cdot 2$

$1 \cdot 6$

$0 \cdot 8$

0.7

$1 \cdot 1$

$0 \cdot 9$

0.5

$1 \cdot 3$

0.9

0.9

$1 \cdot 2$

$1 \cdot 6$

$1 \cdot 2$

0.7

0.9

$1 \cdot 4$

$1 \cdot 2$

$1 \cdot 1$

$1 \cdot 0$

$1 \cdot 0$

0.9

0.6

0.6

$0 \cdot 8$

$1 \cdot 2$

$1 \cdot 1$

$1 \cdot 2$

$1 \cdot 2$

0.6

$1 \cdot 0$

$1 \cdot 1$

$1 \cdot 6$

$1 \cdot 3$

$1 \cdot 4$

$0 \cdot 8$

$1 \cdot 1$

$1 \cdot 3$

0.8

$0 \cdot 7$

6.5

$0 \cdot 9$
$1 \cdot 2$

$-1 \cdot 1$

$-1 \cdot 0$

ND

$-1 \cdot 0$

ND

ND

ND

$-1 \cdot 0$

$-1 \cdot 1$

$1 \cdot 2$

ND

$1 \cdot 0$

$-1 \cdot 1$

ND

$-1 \cdot 0$

$-1 \cdot 1$

ND

$1 \cdot 0$

$-1 \cdot 1$

$-1 \cdot 3$

$1 \cdot 2$

ND

ND

ND

ND

$-1 \cdot 2$

ND

ND

ND

$1 \cdot 0$

ND

$-1 \cdot 1$

$-1 \cdot 0$

$-1 \cdot 1$

$-1 \cdot 1$

$-1 \cdot 1$

$-1 \cdot 1$

ND

$1 \cdot 0$

$-1 \cdot 0$

ND

ND

$-1 \cdot 0$

ND

ND

$-1 \cdot 3$

ND

$-1 \cdot 2$

$1 \cdot 0$

$-1 \cdot 1$

ND

ND

$-1 \cdot 2$

$-1 \cdot 0$

$1 \cdot 1$

ND
$0 \cdot 01$

0.03

$0 \cdot 59$

0.89

$-$

$-$

$0 \cdot 29$

$0 \cdot 14$

$0 \cdot 01$

- 52

$0 \cdot 10$

$0 \cdot 40$

$0 \cdot 04$

0.56

$0 \cdot 34$

$7 \cdot 04 \times 10^{-5}$

$0 \cdot 004$

-

$0 \cdot 3$

$-$

$0 \cdot 01$

$-$

$-$

$0 \cdot 58$

$-$

$0 \cdot 01$

$0 \cdot 12$

0.07

0.03

$0 \cdot 07$

$0 \cdot 06$

$0 \cdot 54$

$0 \cdot 40$

$-$

$0 \cdot 10$

$-$

$2 \cdot 67 \times 10^{-5}$

$-$

$0 \cdot 04$

0.53

$0 \cdot 01$

$-$

$0 \cdot 03$

0.58 
Table 2 Continued

\begin{tabular}{|c|c|c|c|c|}
\hline & \multicolumn{2}{|l|}{ GPCR array } & \multicolumn{2}{|l|}{ Global array } \\
\hline & Relative expression $^{a}$ & Fold change $^{a}$ & Fold change $^{a}$ & $P<$ value \\
\hline P2ry1 & 515 & $0 \cdot 8$ & ND & - \\
\hline Gpr161 & 481 & $1 \cdot 1$ & ND & - \\
\hline Gpr75 & 449 & $0 \cdot 7$ & ND & - \\
\hline Gpr81 & 449 & $0 \cdot 7$ & ND & - \\
\hline Ffar2 & 419 & $2 \cdot 8$ & $1 \cdot 6$ & $3.96 \times 10^{-5}$ \\
\hline Mrgpre & 364 & $1 \cdot 8$ & ND & - \\
\hline Ghsr & 317 & $0 \cdot 7$ & $-1 \cdot 1$ & $0 \cdot 06$ \\
\hline Agtrl1 & 296 & $2 \cdot 2$ & $-1 \cdot 0$ & $0 \cdot 66$ \\
\hline Gpr41 & 296 & $1 \cdot 5$ & ND & - \\
\hline Npy1r & 296 & $0 \cdot 6$ & $-1 \cdot 0$ & 0.93 \\
\hline Adora2b & 258 & $0 \cdot 7$ & $-1 \cdot 1$ & $0 \cdot 26$ \\
\hline Gpr124 & 258 & $0 \cdot 9$ & $-1 \cdot 0$ & $0 \cdot 20$ \\
\hline Gpr63 & 258 & $0 \cdot 8$ & ND & - \\
\hline Cckar & 240 & $11 \cdot 1$ & ND & - \\
\hline Adora2a & 224 & $0 \cdot 7$ & ND & - \\
\hline Gpr19 & 224 & $1 \cdot 1$ & $1 \cdot 1$ & $0 \cdot 03$ \\
\hline Admr & 209 & $1 \cdot 2$ & ND & - \\
\hline Avpr1b & 209 & $0 \cdot 9$ & ND & - \\
\hline Cx3cr1 & 209 & $1 \cdot 1$ & $-1 \cdot 0$ & $0 \cdot 51$ \\
\hline Edg1 & 209 & $1 \cdot 7$ & ND & - \\
\hline Gprc5a & 209 & $0 \cdot 6$ & $-1 \cdot 0$ & $0 \cdot 82$ \\
\hline Ebi2 & 195 & $0 \cdot 8$ & ND & - \\
\hline Gpr4 & 195 & $1 \cdot 7$ & ND & - \\
\hline Sstr1 & 195 & $1 \cdot 0$ & ND & - \\
\hline Celsr1 & 182 & $2 \cdot 2$ & $1 \cdot 1$ & $0 \cdot 03$ \\
\hline Cxcr3 & 182 & $1 \cdot 3$ & ND & - \\
\hline Gpr153 & 182 & $1 \cdot 2$ & ND & - \\
\hline Avpr1a & 170 & $0 \cdot 3$ & $-1 \cdot 0$ & $0 \cdot 61$ \\
\hline Chrm1 & 170 & $0 \cdot 5$ & ND & - \\
\hline Crhr1 & 170 & $0 \cdot 7$ & $-1 \cdot 0$ & $0 \cdot 13$ \\
\hline Gprc6a & 170 & $0 \cdot 6$ & $1 \cdot 0$ & $0 \cdot 50$ \\
\hline P2ry2 & 159 & $0 \cdot 4$ & ND & - \\
\hline Ccr2 & 148 & $1 \cdot 1$ & ND & - \\
\hline Gpr135 & 148 & $1 \cdot 1$ & $1 \cdot 0$ & $0 \cdot 46$ \\
\hline Tbxa2r & 148 & $1 \cdot 4$ & $-1 \cdot 1$ & $0 \cdot 01$ \\
\hline Chrm2 & 138 & $0 \cdot 6$ & ND & - \\
\hline Emr1 & 138 & $1 \cdot 6$ & $-1 \cdot 0$ & $0 \cdot 24$ \\
\hline Fzd1 & 129 & $1 \cdot 4$ & ND & - \\
\hline Gpr109a & 129 & $1 \cdot 4$ & $1 \cdot 0$ & $0 \cdot 30$ \\
\hline Gpr65 & 129 & $0 \cdot 8$ & $-1 \cdot 0$ & $0 \cdot 28$ \\
\hline Galr2 & 129 & $1 \cdot 3$ & ND & - \\
\hline Celsr2 & 129 & $0 \cdot 6$ & ND & - \\
\hline
\end{tabular}

Indicated in bold are the G-protein-coupled receptors that demonstrated a fold change of $>2 \cdot 5$.

${ }^{a}$ Shown are the 100 GPCRs with the greatest expression and their corresponding fold change in pregnant islets compared with those in control. Relative expression was calculated by $2^{C_{\mathrm{t}}(\mathrm{GPCR})-C_{\mathrm{t}} \text { (housekeeping gene) }} \times 10^{5}$. Fold change for the GPCR array and global array were calculated as outlined in section 'Materials and Methods'.

receptor, Htr2b, was increased at mid-gestation while that encoding Htr1d was increased at the end of gestation. In our studies, Htr2b was only weakly expressed in islets from both pregnant and control mice and a clear pregnancy-induced change in expression was not observed; Htr1d mRNA was detectable on day E13.5 but a pregnancy-induced change in the expression was not evident at that time point during pregnancy.

Our studies did exhibit a reproducible pregnancy-induced change in two GPCRs, FFAR2 and CCKAR. Of the two, the role of CCKAR in islets has been more fully examined, with initial studies suggesting that CCKAR plays a role in mediating insulin secretion through CCK binding (Winzell \& Ahren 2007). FFAR2, which exhibited a pregnancyinduced increase in mRNA and protein levels in islets, is a member of a recently identified family of GPCRs that are activated by free fatty acids. This family can be divided by the chain length (long versus short) of the free fatty acids that bind to the receptors. GPCRs that are specific for longchain free fatty acids include GPR 40 (FFAR1) and 


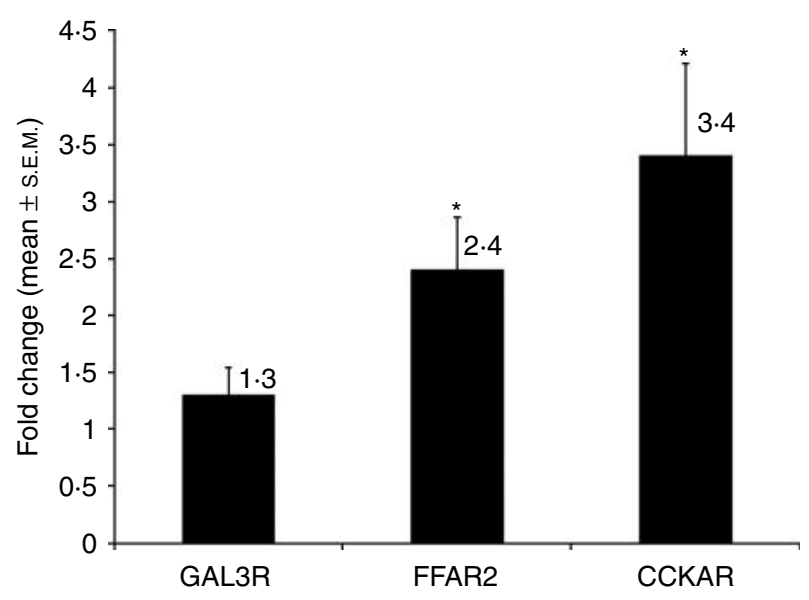

Figure 4 Real-time RT-PCR analysis of GPCR mRNAs regulated by pregnancy in mouse islets at day 13.5 of pregnancy. The fold change in the level of mRNA encoding the following GPCRs, CCKAR, FFAR2, and GAL3R, in islets isolated from pregnant mice (day E13.5) compared with that in age- and sex-matched control mice was determined by real-time RT-PCR. Values are the mean \pm s.E.M. from three independent experiments. The change in the level of each transcript was statistically significant at $P<0 \cdot 05$ (indicated by *), except for GAL3R $(P=0 \cdot 19)$.

GPR120. In contrast, FFAR2 binds specifically to shortchain fatty acids (Kebede et al. 2009). Pregnancy-induced changes in the expression of the mRNAs encoding GPR40 and GPR 120 were not observed. The role of FFAR2 in islets is unclear, although a previous study has demonstrated the expression of FFAR2 in islets (Regard et al. 2007). Moreover, evidence exists that FFAR2 is expressed in $\beta$ cells, at least in pancreatic $\beta$ cell lines (Kebede et al. 2009). Taken together, these data suggest that FFAR2 may be involved in the regulation of islet cell function or mass in pregnancy, although future studies will be required to define its role in islet cell biology.

During the preparation of this manuscript, a study exploring the global RNA expression analysis in islets from pregnant mice was reported (Rieck et al. 2009). These investigators identified 1907 genes that exhibited differential regulation compared with 110 in our study. This difference relates to the use of different analytic approaches. Using an approach similar to that of Rieck et al., we also detected $\sim 1500$ differentially regulated genes. Of the 110 differentially regulated genes identified in our study, 37 were not shown to be differentially regulated (Rieck et al. 2009). A few of the notable exceptions were suppressor of cytokine signaling 2, Ngn3 and ZnT8, genes in which a pregnancyinduced change in expression was verified in our study. These differences may be explained, in part, by differences in the gene expression platforms used and the day of gestation studied, E13.5 vs E14.5.

To date, there are three genes that have been specifically identified as playing a role in gestational diabetes using mouse models. The PRLR, as discussed below, has a clearly established role. The other two genes suggested to be involved in gestational diabetes are FoxM1 and menin. The level of FoxM1 mRNA was shown by Zhang et al. (2010) to be increased on E14.5. Our data show that FoxM1 mRNA levels were increased on E13.5; however, this increase was not statistically significant. Zhang et al. (2010) also developed mice with pancreatic specific null mutations for FoxM1 and found that these mice developed gestational diabetes. The other gene identified as having an important role in gestational diabetes was menin (Karnik et al. 2007). Karnik et al. demonstrated decreased menin mRNA levels in islets during pregnancy, while overexpression of menin led to hyperglycemia during pregnancy. Finally, expression of menin was shown to be regulated by prolactin (Karnik et al. 2007). In our study, a pregnancy-induced change in menin mRNA levels was not demonstrated, although only a single time point in pregnancy was examined.

Increased PRLR expression in islets during pregnancy was demonstrated over 10 years ago (Sorenson \& Brelje 2009). In this report, we have confirmed those findings using the global RNA expression analysis and follow-up confirmation by realtime RT-PCR. Furthermore, a transgenic mouse model has confirmed the role of the PRLR in glucose homeostasis during pregnancy (Huang et al. 2009). Although prolactin signaling undoubtedly contributes to pregnancy-induced changes in $\beta$ cell mass (Sorenson \& Brelje 2009), other signaling pathways and downstream molecules are likely important in this process. Together, with the recently published study by Rieck et al. (2009), our study demonstrates multiple novel proteins that warrant further investigation for their role in pregnancy-induced changes in $\beta$ cells. Many of these genes were not previously known to be regulated by pregnancy, and, in some cases, expression of the gene in islets had not been previously demonstrated. These data should lay the foundation upon which select genes can be more fully examined for their role in pregnancy-induced changes in pancreatic $\beta$ cell function.

\section{Supplementary data}

This is linked to the online version of the paper at http://dx.doi.org/10.1677/ JOE-10-0298.

\section{Declaration of interest}

The authors declare that there is no conflict of interest that could be perceived as prejudicing the impartiality of the research reported.

\section{Funding}

This work was supported by the Endocrine Fellows Foundation Grant (to BTL) and the Northwestern Memorial Foundation MD-Scientist Fellowship (to BTL). 


\section{References}

Aye T, Toschi E, Sharma A, Sgroi D \& Bonner-Weir S 2010 Identification of markers for newly formed $\beta$-cells in the perinatal period: a time of recognized $\beta$-cell immaturity. Journal of Histochemistry and Cytochemistry $\mathbf{5 8}$ 369-376. (doi:10.1369/jhc.2009.954909)

Botas C, Poulain F, Akiyama J, Brown C, Allen L, Goerke J, Clements J, Carlson E, Gillespie AM, Epstein C et al. 1998 Altered surfactant homeostasis and alveolar type II cell morphology in mice lacking surfactant protein D. PNAS 95 11869-11874. (doi:10.1073/pnas.95.20.11869)

Brelje TC, Scharp DW, Lacy PE, Ogren L, Talamantes F, Robertson M, Friesen HG \& Sorenson RL 1993 Effect of homologous placental lactogens, prolactins, and growth hormones on islet B-cell division and insulin secretion in rat, mouse, and human islets: implication for placental lactogen regulation of islet function during pregnancy. Endocrinology 132 879-887. (doi:10.1210/en.132.2.879)

Butler PC, Meier JJ, Butler AE \& Bhushan A 2007 The replication of $\beta$ cells in normal physiology, in disease and for therapy. Nature Clinical Practice. Endocrinology and Metabolism 3 758-768. (doi:10.1038/ncpendmet0647)

Chen X, Zhang X, Larson CS, Baker MS \& Kaufman DB 2006 In vivo bioluminescence imaging of transplanted islets and early detection of graft rejection. Transplantation 81 1421-1427. (doi:10.1097/01.tp.0000206109. 71181.bf)

Chimienti F, Devergnas S, Pattou F, Schuit F, Garcia-Cuenca R, Vandewalle B, Kerr-Conte J, Van Lommel L, Grunwald D, Favier A et al. 2006 In vivo expression and functional characterization of the zinc transporter $\mathrm{ZnT} 8$ in glucose-induced insulin secretion. Journal of Cell Science 119 4199-4206. (doi:10.1242/jcs.03164)

Crouch E, Persson A \& Chang D 1993 Accumulation of surfactant protein D in human pulmonary alveolar proteinosis. American Journal of Pathology 142 241-248.

De Leon DD, Deng S, Madani R, Ahima RS, Drucker DJ \& Stoffers DA 2003 Role of endogenous glucagon-like peptide-1 in islet regeneration after partial pancreatectomy. Diabetes 52 365-371. (doi:10.2337/diabetes. 52.2.365)

Dif F, Saunier E, Demeneix B, Kelly PA \& Edery M 2001 Cytokine-inducible SH2-containing protein suppresses PRL signaling by binding the PRL receptor. Endocrinology 142 5286-5293. (doi:10.1210/en.142.12.5286)

Du P, Kibbe WA \& Lin SM 2008 Lumi: a pipeline for processing Illumina microarray. Bioinformatics 24 1547-1548. (doi:10.1093/bioinformatics/ btn224)

Egefjord L, Jensen JL, Bang-Berthelsen CH, Petersen AB, Smidt K, Schmitz O, Karlsen AE, Pociot F, Chimienti F, Rungby J et al. 2009 Zinc transporter gene expression is regulated by pro-inflammatory cytokines: a potential role for zinc transporters in $\beta$-cell apoptosis? BMC Endocrine Disorders 9 7. (doi:10.1186/1472-6823-9-7)

El Muayed M, Billings LK, Raja MR, Zhang X, Park PJ, Newman MV, Kaufman DB, O'Halloran TV \& Lowe WL Jr 2010 Acute cytokinemediated downregulation of the zinc transporter $\mathrm{ZnT} 8$ alters pancreatic $\beta$-cell function. Journal of Endocrinology 206 159-169. (doi:10.1677/JOE09-0420)

Fleige S, Walf V, Huch S, Prgomet C, Sehm J \& Pfaffl MW 2006 Comparison of relative mRNA quantification models and the impact of RNA integrity in quantitative real-time RT-PCR. Biotechnology Letters 28 1601-1613. (doi:10.1007/s10529-006-9127-2)

Fredriksson R \& Schioth HB 2005 The repertoire of G-protein-coupled receptors in fully sequenced genomes. Molecular Pharmacology 67 1414-1425. (doi:10.1124/mol.104.009001)

Gu G, Dubauskaite J \& Melton DA 2002 Direct evidence for the pancreatic lineage: NGN3 + cells are islet progenitors and are distinct from duct progenitors. Development 129 2447-2457.

Guo CJ, Atochina-Vasserman EN, Abramova E, Foley JP, Zaman A, Crouch E, Beers MF, Savani RC \& Gow AJ 2008 S-nitrosylation of surfactant protein-D controls inflammatory function. PLoS Biology 6 e266. (doi:10. 1371/journal.pbio.0060266)

Holz GG \& Chepurny OG 2005 Diabetes outfoxed by GLP-1? Science's STKE 2005 pe2. (doi:10.1126/stke.2682005pe2)
Huang C, Snider F \& Cross JC 2009 Prolactin receptor is required for normal glucose homeostasis and modulation of $\beta$-cell mass during pregnancy. Endocrinology 150 1618-1626. (doi:10.1210/en.2008-1003)

Karnik SK, Chen H, McLean GW, Heit JJ, Gu X, Zhang AY, Fontaine M, Yen MH \& Kim SK 2007 Menin controls growth of pancreatic $\beta$-cells in pregnant mice and promotes gestational diabetes mellitus. Science $\mathbf{3 1 8}$ 806-809. (doi:10.1126/science.1146812)

Kebede MA, Alquier T, Latour MG \& Poitout V 2009 Lipid receptors and islet function: therapeutic implications? Diabetes, Obesity and Metabolism 11 (Supplement 4) 10-20. (doi:10.1111/j.1463-1326.2009.01114.x)

Kim H, Toyofuku Y, Lynn FC, Chak E, Uchida T, Mizukami H, Fujitani Y, Kawamori R, Miyatsuka T, Kosaka Y et al. 2010 Serotonin regulates pancreatic $\beta$ cell mass during pregnancy. Nature Medicine 16 804-808. (doi:10.1038/nm.2173)

Lemaire K, Ravier MA, Schraenen A, Creemers JW, Van de Plas R, Granvik M, Van Lommel L, Waelkens E, Chimienti F, Rutter GA et al. 2009 Insulin crystallization depends on zinc transporter ZnT8 expression, but is not required for normal glucose homeostasis in mice. PNAS 106 14872-14877. (doi:10.1073/pnas.0906587106)

Leth-Larsen R, Holmskov U \& Hojrup P 1999 Structural characterization of human and bovine lung surfactant protein D. Biochemical Journal 343 645-652. (doi:10.1042/0264-6021:3430645)

MacDonald MJ 2007 Synergistic potent insulin release by combinations of weak secretagogues in pancreatic islets and INS-1 cells. Journal of Biological Chemistry 282 6043-6052. (doi:10.1074/jbc.M606652200)

Madsen J, Kliem A, Tornoe I, Skjodt K, Koch C \& Holmskov U 2000 Localization of lung surfactant protein $\mathrm{D}$ on mucosal surfaces in human tissues. Journal of Immunology 164 5866-5870.

Matalon S, Shrestha K, Kirk M, Waldheuser S, McDonald B, Smith K, Gao Z, Belaaouaj A \& Crouch EC 2009 Modification of surfactant protein D by reactive oxygen-nitrogen intermediates is accompanied by loss of aggregating activity in vitro and in vivo. FASEB Journal 23 1415-1430. (doi:10.1096/fj.08-120568)

Motwani M, White RA, Guo N, Dowler LL, Tauber AI \& Sastry KN 1995 Mouse surfactant protein-D. cDNA cloning, characterization, and gene localization to chromosome 14. Journal of Immunology 155 5671-5677.

Nicolson TJ, Bellomo EA, Wijesekara N, Loder MK, Baldwin JM, Gyulkhandanyan AV, Koshkin V, Tarasov AI, Carzaniga R, Kronenberger K et al. 2009 Insulin storage and glucose homeostasis in mice null for the granule zinc transporter $\mathrm{ZnT} 8$ and studies of the type 2 diabetes-associated variants. Diabetes 58 2070-2083. (doi:10.2337/db09-0551)

Paulmann N, Grohmann M, Voigt JP, Bert B, Vowinckel J, Bader M, Skelin M, Jevsek M, Fink H, Rupnik M et al. 2009 Intracellular serotonin modulates insulin secretion from pancreatic $\beta$-cells by protein serotonylation. PLoS Biology 7 e1000229. (doi:10.1371/journal.pbio.1000229)

Regard JB, Kataoka H, Cano DA, Camerer E, Yin L, Zheng YW, Scanlan TS, Hebrok M \& Coughlin SR 2007 Probing cell type-specific functions of G(i) in vivo identifies GPCR regulators of insulin secretion. Journal of Clinical Investigation 117 4034-4043. (doi:10.1172/JCI32994)

Richardson AC \& Carpenter MW 2007 Inflammatory mediators in gestational diabetes mellitus. Obstetrics and Gynecology Clinics of North America 34 213-224. (doi:10.1016/j.ogc.2007.04.001)

Rieck S, White P, Schug J, Fox AJ, Smirnova O, Gao N, Gupta RK, Wang ZV, Scherer PE, Keller MP et al. 2009 The transcriptional response of the islet to pregnancy in mice. Molecular Endocrinology 23 1702-1710. (doi:10.1210/ me.2009-0144)

Sauter NS, Schulthess FT, Galasso R, Castellani LW \& Maedler K 2008 The antiinflammatory cytokine interleukin-1 receptor antagonist protects from high-fat diet-induced hyperglycemia. Endocrinology 149 2208-2218. (doi:10.1210/en.2007-1059)

Schrader J, Rennekamp W, Niebergall U, Schoppet M, Jahr H, Brendel MD, Horsch D \& Hofbauer LC 2007 Cytokine-induced osteoprotegerin expression protects pancreatic $\beta$ cells through p38 mitogen-activated protein kinase signalling against cell death. Diabetologia 50 1243-1247. (doi:10.1007/s00125-007-0672-6) 
Sladek R, Rocheleau G, Rung J, Dina C, Shen L, Serre D, Boutin P, Vincent D, Belisle A, Hadjadj S et al. 2007 A genome-wide association study identifies novel risk loci for type 2 diabetes. Nature 445 881-885. (doi:10.1038/nature05616)

Snyder GD, Oberley-Deegan RE, Goss KL, Romig-Martin SA, Stoll LL, Snyder JM \& Weintraub NL 2008 Surfactant protein D is expressed and modulates inflammatory responses in human coronary artery smooth muscle cells. American Journal of Physiology. Heart and Circulatory Physiology 294 H2053-H2059. (doi:10.1152/ajpheart.91529.2007)

Sorenson RL \& Brelje TC 2009 Prolactin receptors are critical to the adaptation of islets to pregnancy. Endocrinology 150 1566-1569. (doi:10. 1210/en.2008-1710)

Sørensen GL, Hjelmborg JV, Leth-Larsen R, Schmidt V, Fenger M, Poulain F, Hawgood S, Sorensen TI, Kyvik KO \& Holmskov U 2006a Surfactant protein $\mathrm{D}$ of the innate immune defence is inversely associated with human obesity and SP-D deficiency infers increased body weight in mice. Scandinavian Journal of Immunology 64 633-638. (doi:10.1111/j.1365-3083. 2006.01853.x)

Sørensen GL, Madsen J, Kejling K, Tornoe I, Nielsen O, Townsend P, Poulain F, Nielsen CH, Reid KB, Hawgood S et al. $2006 b$ Surfactant protein D is proatherogenic in mice. American Journal of Physiology. Heart and Circulatory Physiology 290 H2286-H2294. (doi:10.1152/ajpheart.01105.2005)

Sørensen GL, Husby S \& Holmskov U 2007 Surfactant protein A and surfactant protein D variation in pulmonary disease. Immunobiology 212 381-416. (doi:10.1016/j.imbio.2007.01.003)

Sørensen GL, Hoegh SV, Leth-Larsen R, Thomsen TH, Floridon C, Smith K, Kejling K, Tornoe I, Crouch EC \& Holmskov U 2009 Multimeric and trimeric subunit SP-D are interconvertible structures with distinct ligand interaction. Molecular Immunology 46 3060-3069. (doi:10.1016/j.molimm. 2009.06.005)

Soyer J, Flasse L, Raffelsberger W, Beucher A, Orvain C, Peers B, Ravassard P, Vermot J, Voz ML, Mellitzer G et al. 2010 Rfx6 is an Ngn3-dependent winged helix transcription factor required for pancreatic islet cell development. Development 137 203-212. (doi:10.1242/dev.041673)

Sutherland KD, Lindeman GJ \& Visvader JE 2007 Knocking off SOCS genes in the mammary gland. Cell Cycle 6 799-803.

Vandesompele J, De Preter K, Pattyn F, Poppe B, Van Roy N, De Paepe A \& Speleman F 2002 Accurate normalization of real-time quantitative
RT-PCR data by geometric averaging of multiple internal control genes. Genome Biology 3 RESEARCH0034. (doi:10.1186/gb-2002-3-7research0034)

Vasavada RC, Cavaliere C, D'Ercole AJ, Dann P, Burtis WJ, Madlener AL, Zawalich K, Zawalich W, Philbrick W \& Stewart AF 1996 Overexpression of parathyroid hormone-related protein in the pancreatic islets of transgenic mice causes islet hyperplasia, hyperinsulinemia, and hypoglycemia. Journal of Biological Chemistry 271 1200-1208. (doi:10.1074/jbc.271.40. 24371)

Wenzlau JM, Juhl K, Yu L, Moua O, Sarkar SA, Gottlieb P, Rewers M, Eisenbarth GS, Jensen J, Davidson HW et al. 2007 The cation efflux transporter ZnT8 (Slc30A8) is a major autoantigen in human type 1 diabetes. PNAS 104 17040-17045. (doi:10.1073/pnas. 0705894104)

Winzell MS \& Ahren B 2007 G-protein-coupled receptors and islet function - implications for treatment of type 2 diabetes. Pharmacology and Therapeutics 116 437-448. (doi:10.1016/j.pharmthera.2007.08.002)

Xiao SH, Reagan JD, Lee PH, Fu A, Schwandner R, Zhao X, Knop J, Beckmann H \& Young SW 2008 High throughput screening for orphan and liganded GPCRs. Combinatorial Chemistry \& High Throughput Screening 11 195-215. (doi:10.2174/138620708783877762)

Zhang H, Zhang J, Pope CF, Crawford LA, Vasavada RC, Jagasia SM \& Gannon M 2010 Gestational diabetes mellitus resulting from impaired $\beta$-cell compensation in the absence of FoxM1, a novel downstream effector of placental lactogen. Diabetes 59 143-152. (doi:10.2337/ db09-0050)

Zhao XM, Wu YP, Wei R, Cai HX, Tornoe I, Han JJ, Wang Y, de Groot PG, Holmskov U, Xia ZL et al. 2007 Plasma surfactant protein D levels and the relation to body mass index in a chinese population. Scandinavian Journal of Immunology 66 71-76. (doi:10.1111/j.1365-3083. 2007.01943.x)

Received in final form 10 September 2010

Accepted 16 September 2010

Made available online as an Accepted Preprint 16 September 2010 